\title{
COVID-19 situation in India: Artifact or Fact?
}

\author{
Kanchan Mukherjee \\ Professor \\ Centre for Health Policy, Planning and Management \\ School of Health Systems Studies \\ TISS, Mumbai, India
}

\begin{abstract}
One year after the SARS-CoV-2 virus was first reported, India holds the dubious distinction of having the second highest number of SARS-CoV-2 cases in the world. Accurate and reliable testing holds the key for effective surveillance and management of this pandemic. In this context, this study analyses the course of the pandemic in India tracing back to the beginning of the national lockdown and the subsequent eleven months. It uses the variables of testing speed and incremental change in cases over time to draw insights into the current situation. The incremental analysis findings are triangulated with the published findings of the second national household serosurveillance from India and the Health Technology Assessment (HTA) of the FELUDA diagnostic test; to understand the nuances with the current data and testing technology for drawing inferences. The study finds that even with the availability of better local testing technology and evidence, the testing policy has failed to incorporate them, resulting in inaccurate, unreliable data and spread of infection. The findings reveal the gap between science and policy in India which has implications for both policy makers and researchers. Unless this gap is bridged urgently, the Indian situation may easily become one of global sore points in the fight against this pandemic.
\end{abstract}

\section{Study implications}

For policy makers: Need to revise the existing SARS-CoV-2 testing policy in India based on evidence on cost effectiveness of new diagnostic technology and findings from the national serosurvey studies.

For researchers: The starting point of any modeling or prediction studies of this pandemic in India will need to take into consideration the extent of undetected cases estimated to be 26-32 infections for every positive case reported. 


\section{Introduction}

It has been over a year since the first case of SARS-CoV-2 was reported in India (January 30, 2020). ${ }^{1}$ To address the spread of SARS-CoV-2 in India, a national lockdown was imposed for 68 days from March 25 to May 31, 2020. After this lockdown period, India went through different phases of 'unlock' period as per the decisions of various state governments based on local situation. Also, testing policies and strategies were changed during this period of time. As on March 11, 2021 India has the second highest number of SARS-CoV-2 cases in the world. ${ }^{2}$ The World Health Organization (WHO) has from the very early stages of this pandemic stressed the need for accurate data on cases which is critical for the management of this pandemic and is dependent on reliable testing. ${ }^{3}$ In this context, this study aims to provide insights into the COVID-19 situation in India through a longitudinal analysis of the official data on testing rates, cases, polices and published evidence.

\section{Methodology}

The study is a longitudinal observational study based on analysis of secondary data. Official data on SARS-CoV-2 testing rates and cases available in the public domain (our world in data database) has been used for this study. In addition, official federal/union advisories on testing policies and strategies, state specific official testing data and published literature on health technology assessments (HTA) and serosurveillance done during this period have been reviewed. Data triangulation was done from all the above sources to provide insights into the current situation.

\section{Results and discussion}

Between January 30 to mid-June 2020, India's testing strategy was based solely on the Reverse Transcriptase-Polymerase Chain Reaction (RT-PCR) test (gold standard). However, on June 14, 2020 an advisory ${ }^{4}$ was issued to the states and union territories which permitted the use of a Rapid Antigen Test (RAT) for testing SARS-CoV-2. The RAT approved in India has shown to be highly specific (99-100\%) but only moderately sensitive (50.6-84\%) ${ }^{4}$ Hence, the testing protocol and subsequent advisories ${ }^{5,6}$ included a RT-PCR test to be done for all the symptomatic negatives of the RAT to avoid false negatives which can be very high in this rapid test. Since, the RAT is less resource intensive and faster, its use has increased significantly for population testing since the issue of this advisory. However, compliance with follow up RT-PCR for RAT negative individuals has been poor and the use of RT-PCR has fallen or stagnated during this period. By December 2020, almost 40 per cent of all Covid-19 tests done in India were rapid antigen test. However, there are regional variations with Tamil Nadu testing almost entirely through RT-PCR, while six states reporting more than 50\% use of RAT test. These states include Uttar Pradesh (60\%), Kerala (63\%), Delhi (69\%), Gujarat (78\%), Telangana (83\%) and Bihar $(88 \%){ }^{7}$

Table 1 presents a longitudinal incremental analysis of testing rates and cases since the national lockdown in India in equal blocks of time (68 days). At the end of the lockdown period (May 31) which lasted 68 days, testing rates (through RT-PCR) had increased by 150 times while cases had increased 290 times. This national level pattern reflects a similar pattern emerging from Mumbai (COVID-19 hotspot) suggesting that the virus had spread in the community before the lockdown started. ${ }^{8}$ On June 1, 2020, India began the 'unlock' phase and a comparative analysis shows that the situation became worse in the unlock phase. The incremental increase in cases/testing rate (ICTR) in the first 68 days of the unlock phase (137.65) was almost double than that during the lockdown phase (70.61) indicating a much higher spread of infection, 
although the testing speed had decreased significantly in this period as compared to the lockdown phase.

Table 1: Longitudinal incremental analysis of testing rates and cases in India (March 25, 2020 to February 27, 2021) (Data source: Our world in data database)

\begin{tabular}{|c|c|c|c|c|c|c|c|}
\hline \multirow[b]{2}{*}{ Time } & \multicolumn{2}{|c|}{ Day 1} & \multicolumn{2}{|c|}{ Day 68} & \multirow{2}{*}{$\begin{array}{c}\text { Increase } \\
\text { in testing } \\
\text { rate in } 68 \\
\text { days } \\
(\mathrm{T} 2 / \mathrm{T} 1) \\
\text { (Testing } \\
\text { speed) }\end{array}$} & \multirow{2}{*}{$\begin{array}{c}\text { Increase } \\
\text { in cases } \\
(\mathrm{S} 2 / \mathrm{S} 1) \\
\text { in } 68 \text { days }\end{array}$} & \multirow{2}{*}{$\begin{array}{c}\text { Incremental } \\
\text { change } \\
\text { Cases/testing } \\
\text { rate } \\
\text { [S2-S1/T2-T1] } \\
\text { (ICTR) }\end{array}$} \\
\hline & $\begin{array}{c}\text { Testing rate } \\
\text { (Tests/million) } \\
\text { (T1) }\end{array}$ & $\begin{array}{c}\text { SARS- } \\
\text { CoV-2 } \\
\text { cases } \\
\text { (S1) }\end{array}$ & $\begin{array}{c}\text { Testing rate } \\
\text { (Tests/million) } \\
\text { (T2) }\end{array}$ & $\begin{array}{c}\text { SARS- } \\
\text { CoV-2 } \\
\text { cases } \\
(\mathrm{S} 2)\end{array}$ & & & \\
\hline $\begin{array}{l}\text { National } \\
\text { lockdown } \\
\text { phase } \\
\text { (68 days) } \\
\text { March 25- } \\
\text { May 31, } \\
2020\end{array}$ & 18 & 657 & 2708 & 190609 & 150.44 & 290.12 & 70.61 \\
\hline $\begin{array}{c}\text { Next } 68 \\
\text { days } \\
\text { (Unlock } \\
\text { phase) } \\
\text { June1 to } \\
\text { August 7, } \\
2020\end{array}$ & 2781 & 198370 & 16513 & 2088611 & 5.93 & 10.92 & 137.65 \\
\hline $\begin{array}{c}\text { Next } 68 \\
\text { days (unlock } \\
\text { phase) } \\
\text { August } 8 \text { to } \\
\text { October } 14, \\
2020\end{array}$ & 16947 & 2153010 & 65282 & 7307097 & 3.85 & 3.39 & 106.63 \\
\hline $\begin{array}{l}\text { Next } 68 \\
\text { days (unlock } \\
\text { phase) } \\
\text { October } 15 \\
\text { to December } \\
21,2020\end{array}$ & 66106 & 7370468 & 117462 & 10075116 & 1.77 & 1.36 & 52.66 \\
\hline $\begin{array}{c}\text { Next } 68 \\
\text { days (unlock } \\
\text { phase) } \\
\text { December } \\
22,2020 \text { to } \\
\text { February 27, } \\
2021\end{array}$ & 118239 & 10099066 & 156112 & 11096731 & 1.32 & 1.09 & 26.34 \\
\hline
\end{tabular}


Figure one gives a comparative snapshot picture of the trends in testing rates, testing speed and incremental cases/testing rate in the last 11 months.

Figure 1: Trends in testing rates, testing speed and ICTR (March 25, 2020 to February 27, 2021)

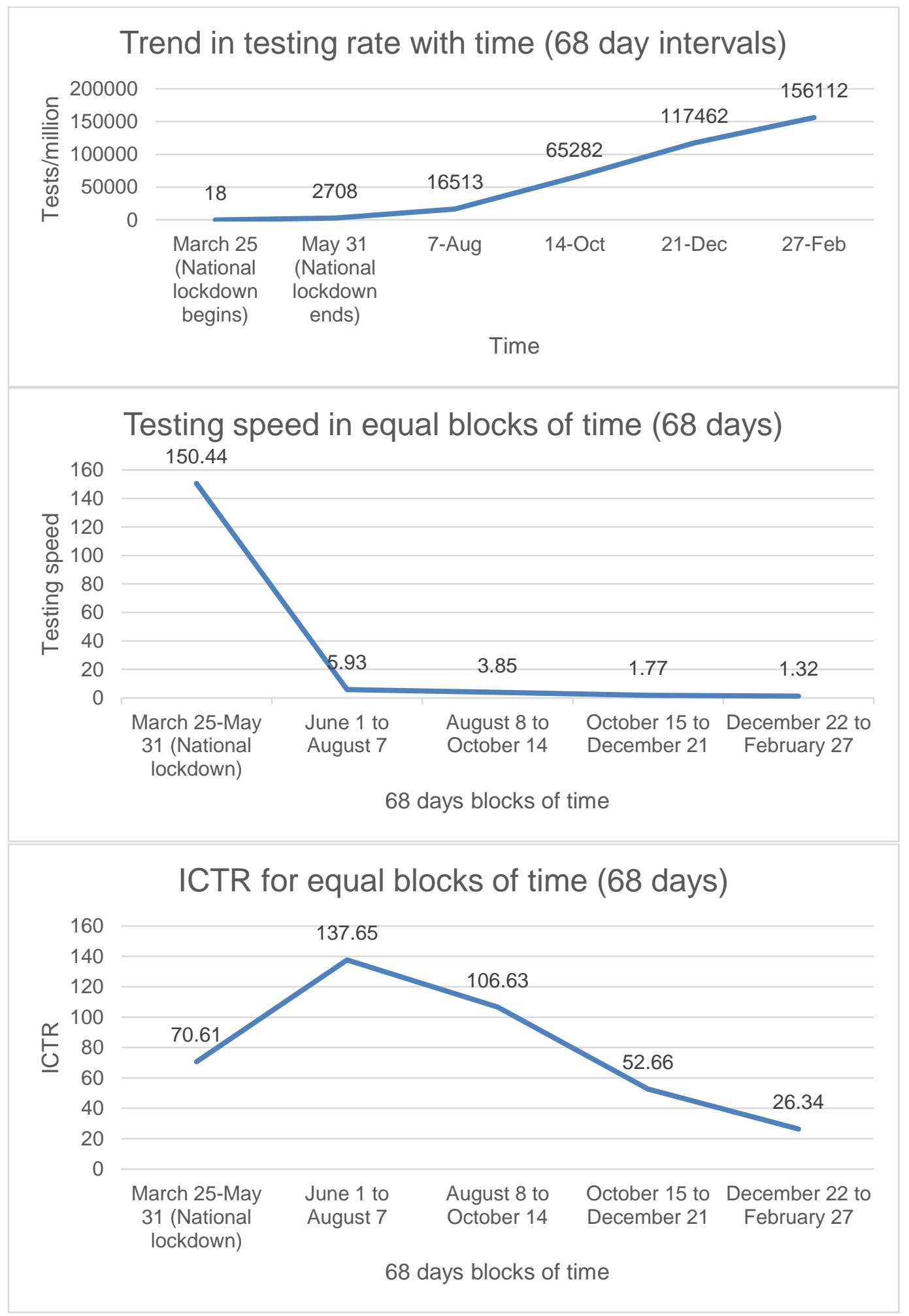




\section{Discussion}

As seen from table 1 and figure 1, the time between June to mid-October 2020 shows the highest spread of infection with over 100 cases detected per unit change in testing rate. However, the speed of testing had decreased significantly during this period and has continued to decrease in the subsequent equal blocks of time. The 'decrease in case increase' with time is therefore representing an artifact due to the decrease in testing speed, in spite of the use of RAT which was started in the unlock phase and gave faster results. Also, the situation is further complicated by the poor implementation of the RAT+RT-PCR testing protocol, resulting in missing many of the false negatives from the RAT.

This has resulted in serious public health consequences. Firstly, it is adversely affecting the accuracy of data for effective case management and prevention strategies. The use of RAT negative test to rule out SARS-CoV-2 (without RT-PCR) is resulting in missing many people who may be actually infected and resulting in underestimation of cases. Secondly, as these people remain outside the test-track-isolate strategy, they remain potentially infectious to others in the community and can spread the infection among their contacts. Thirdly, the focus on doing RT-PCR only on symptomatic RAT negative individuals is against the well-established global evidence on asymptomatic transmission.

A quantitative value to the above implications emerge from the findings from the second national serosurvey from India, which finds 26-32 infections for every reported case, increasing spread of the virus to rural areas and only $3 \%$ of seropositive individuals reporting symptoms, highlighting the limitations of symptom-directed testing. ${ }^{9}$ During the last six months there have been many innovative developments in testing technology including newer better quality rapid antigen tests and the FELUDA diagnostic test which has shown to be cost effective for the health systems ${ }^{10}$ and approved for use by India's medical device approval authority. However, while private hospitals have started procuring the FELUDA testing kits, it is not available in public hospitals. Triangulating the evidence from this incremental analysis with the findings of the national serosurveillance data and the HTA on FELUDA test, Table 2 gives a summary of the key findings.

Table 2: Summary of findings from data triangulation

\begin{tabular}{|c|c|c|}
\hline $\begin{array}{c}\text { Findings from the longitudinal } \\
\text { analysis }\end{array}$ & $\begin{array}{c}\text { Peer reviewed published } \\
\text { findings from the second } \\
\text { national serosurvey }\end{array}$ & $\begin{array}{c}\text { Peer reviewed published } \\
\text { findings from the HTA on } \\
\text { newer testing technology } \\
\text { (FELUDA) }\end{array}$ \\
\hline $\begin{array}{c}\text { Underestimation of cases due } \\
\text { to poor implementation of } \\
\text { RAT+RT-PCR testing protocol } \\
\text { resulting in inaccurate data }\end{array}$ & $\begin{array}{c}26-32 \text { infections for every } \\
\text { reported case }\end{array}$ & $\begin{array}{c}\text { FELUDA test shown to have } \\
\text { similar accuracy as the gold } \\
\text { standard RT-PCR; with less } \\
\text { cost, skill and time } \\
\text { requirements }\end{array}$ \\
\hline $\begin{array}{c}\text { Spread of infection due to } \\
\text { false negative RAT individuals } \\
\text { remaining outside the isolation } \\
\text { strategy }\end{array}$ & $\begin{array}{c}\text { Increasing spread of the virus } \\
\text { to rural areas when compared } \\
\text { to first serosurvey }\end{array}$ & $\begin{array}{c}\text { False negative rate of } \\
\text { FELUDA (4\%) very low as } \\
\text { compared to RAT (16-50\%) }\end{array}$ \\
\hline $\begin{array}{c}\text { Symptomatic testing does not } \\
\text { add value }\end{array}$ & $\begin{array}{c}\text { Only 3\% of seropositive } \\
\text { individuals reported symptoms }\end{array}$ & $\begin{array}{c}\text { Cost effective for } \\
\text { asymptomatic case detection }\end{array}$ \\
\hline
\end{tabular}




\section{Conclusions}

The understanding and management of the COVID-19 situation in any country is dependent on the data reported. The accuracy and reliability of data are key determinants for effective management. This study finds that the current Indian COVID-19 data is an artifact due to a 'created' situation resulting from an outdated testing policy compounded by poor implementation. However, the causes of this artifact are all rectifiable and once rectified would increase the accuracy of data to reflect the actual situation. It has been over six months since the last testing advisory was issued (September 4,2020 ) during which time new technologies and new evidences have emerged from within India. The testing protocol should incorporate these technologies and evidences into revising the national testing policy so that we have a cost effective, accurate, reliable and sustainable COVID-19 surveillance system. With the vaccine roll out happening in India and a large amount of resources (human and financial) being used for vaccination, it becomes even more important that cost effective tests with better accuracy requiring less resources, skill and time are introduced. Since COVID-19 surveillance is playing a critical role in this pandemic, the results of this study has implications for future testing policies, lockdown policies in India as well as international travel policies, modeling studies and global surveillance. Hence, there is an urgent need to address the causes of this artifact not only in the interest of India's population but also global health.

\section{References}

1. Ministry of Health and Family Welfare (MOHFW). Press Information Bureau (PIB). Government of India. Update on Novel Coronavirus: one positive case reported in Kerala. Jan 30, 2020. https://pib.gov.in/PressReleaseIframePage.aspx?PRID=1601095 (accessed March 9, 2021)

2. World Health Organization. WHO Corona virus (COVID-19) dashboard. Available from: https://covid19.who.int/table. (accessed March 9, 2021).

3. World Health Organization (WHO). Emergencies Press Conference on corona virus disease outbreak (March18,2020).https://www.who.int/docs/defaultsource/coronaviruse/transcripts/who-audio-emergencies-coronavirus-press-conference-full18mar2020b4d4018fc1904605831b6a08d31e0cbc.pdf?sfvrsn=1f444736_8. (accessed March 9, 2021).

4. Indian Council of Medical Research (ICMR). Government of India. Advisory on Use of Rapid Antigen Detection Test for COVID-19. June 14, 2020.

https://www.icmr.gov.in/pdf/covid/strategy/Advisory_for_rapid_antigen_test14062020.pdf (accessed March 8, 2021)

5. ICMR. Government of India. Advisory on Newer Additional Strategies for COVID-19

Testing. June 23, 2020.

https://www.icmr.gov.in/pdf/covid/strategy/New_additional_Advisory_23062020_3.pdf (accessed March 8, 2021) 
6. ICMR. Government of India. Advisory on Strategy for COVID-19 Testing in India (Version VI). September 4, 2020.

https://www.icmr.gov.in/pdf/covid/strategy/Testing_Strategy_v6_04092020.pdf (accessed March $8,2021)$

7. Menon S. Coronavirus: Is India's test and tracing strategy working? December 4, 2020 https://www.bbc.com/news/world-asia-india-55083825 (accessed March 9, 2021)

8. Mukherjee K. COVID-19 and lockdown: Insights from Mumbai. Indian J Public Health. 2020 Jun; 64 (Supplement): S168-S171. https://pubmed.ncbi.nlm.nih.gov/32496249/

9. Murhekar MV, Bhatnagar T, Selvaraju S et al. SARS-CoV-2 antibody seroprevalence in India, August-September, 2020: findings from the second nationwide household serosurvey Lancet Glob Health 2021; 9: e257-66.

10. Mukherjee K. Integrating technology, innovation and policy: COVID-19 and HTA. Health Policy and Technology. 10 (2021): 16-20. https://doi.org/10.1016/j.hlpt.2021.01.003 